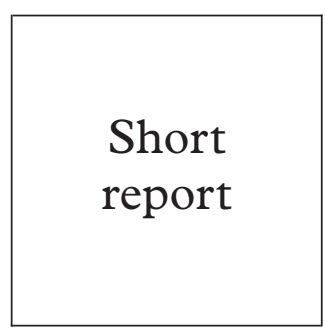

\title{
Low prevalence of hepatitis B markers among Mexican female sex workers
}

\author{
L Juárez-Figueroa, F Uribe-Salas, C Conde-Glez, M Hernández-Avila, \\ M Olamendi-Portugal, P Uribe-Zúñiga, E Calderón
} Objectives: To estimate the prevalence and associated risk factors of hepatitis B virus (HBV)
serological markers in female sex workers (FSW) in Mexico City.

Methods: The study population consisted of 1498 FSW who attended a detection centre for human immunodeficiency virus (HIV) in Mexico City, between January and October 1992. Study participants responded to a standardised questionnaire and provided a blood sample for serology of syphilis, HIV, and HBV.

Results: A total of $0.2 \%(95 \%$ CI $0.1-0.3)$ of the population were hepatitis B surface antigen (HBsAg) carriers. The general prevalence of antibodies to hepatitis B core antigen (anti-HBc) was $6.3 \%$ (95\% CI 5.5-7.1). This marker of previous exposition to HBV, was independently associated by logistic regression multivariate analysis with age, working in the street, and history of blood transfusion (BT) before 1987 (OR 4.8, 95\% CI 2.1-11.3). Syphilis prevalence was 7.6\% (95\% CI 6.2-8.9) and HIV prevalence was $0.1 \%$ (95\% CI 0-0.3).

Conclusions: The prevalence of HBV infection in this group of Mexican FSW is lower than previously reported in other countries. In addition, the frequency of HBsAg carriers is similar to that in the general Mexican population. The absence of two major risk factors for HBV transmission in this group of FSW-that is, injecting drug use and anal intercourse, could help to explain this finding. However, the positive association between anti-HBc and history of blood transfusion demonstrated here, highlights the need to reinforce strict control of blood supplies in Mexico. (Sex Transm Inf 1998;74:448-450)

Keywords: hepatitis B; female sex workers; seroprevalence

\section{Introduction}

Several studies have demonstrated that Mexico, together with Canada and the United States, has low hepatitis B endemicity. According to a serological survey carried out in general urban populations throughout Mexico in 1970 the prevalence of hepatitis B surface antigen (HBsAg) was on average $0.29 \%,{ }^{1}$ and for nationwide unpaid family blood donors during 1990-2 the prevalence of hepatitis B virus (HBV) carriers ranged from $0.2 \%$ to $0.8 \% .^{2}$ In particular, few studies have described the prevalence of HBV markers in high risk groups for sexually transmitted diseases (STD) in Mexico. In a male homosexual group we found $4.8 \% \mathrm{HBsAg}$ carriers, ${ }^{3}$ whereas other authors reported $0.8 \%$ in female sex workers (FSW) from the Mexico-US border. ${ }^{4}$ The present study describes the prevalence of $\mathrm{HBV}$ markers and risk factors associated with $\mathrm{HBV}$ infection in a population of FSW who voluntarily attend an HIV/STD information and detection centre in Mexico City.

\section{Material and methods}

POPULATION STUDIED

Inclusion criteria for the study population was voluntary attendance at a centre for HIV/STD detection in female sex workers (CONASIDA) between January and October 1992 in Mexico City. No exclusion criteria were applied. This study included 1498 FSW, all of whom answered a questionnaire regarding socioeconomic and demographic characteristics, history of blood transfusion, injecting drug use, and other risk factors associated with STD.

BIOLOGICAL SAMPLE

After obtaining informed consent from each subject, a venous blood sample was taken. Blood samples were sent to the National Institute of Public Health and sera were tested for HBsAg by ELISA (Hepanostika HBsAg, Organon Teknica, Boxtel, Holland). HBV carriers identified through a positive result were retested with the same test for secondary confirmation. Those samples which were confirmed positive were additionally tested using a neutralisation assay provided by the same manufacturer. Prevalence of previous exposure to the virus was assessed using a competitive ELISA test (Hepanostika anti-HBc, Organon, Teknica, Boxtel, Holland) which detects anti$\mathrm{HBc}$ antibodies. If two consecutive tests resulted in an optical density below a "grey area" equal to $66 \%$ of the cut off set by the manufacturer, the sample was considered anti$\mathrm{HBc}$ positive. An automatic Biomeck 1000 station (Beckman Instruments, USA) was used to process samples.

All samples were subjected to the rapid plasma reagin (RPR) test (Bigaux Diagnostica, Mexico), and positive sera were confirmed by the fluorescent Treponema antibody (FTAAbs) assay (Pasteur Diagnostic, Marnes la Coquette, France). Presence of anti-HIV antibody was assayed using an ELISA (RapidELAVIA, Pasteur Diagnostic, Marnes la Coquette, France), and positive results were confirmed by 
Table 1 Crude odds ratio of anti-HBc among Mexican female sex workers, by sociodemographic characteristics, sexual behaviour, history of blood transfusion, and syphilis serology during 1993

\begin{tabular}{|c|c|c|c|c|}
\hline Variable & $\mathrm{No}^{\star}$ & Prevalence & $O R$ & $95 \% C I$ \\
\hline \multicolumn{5}{|l|}{ Age (years): } \\
\hline $16-22$ & 394 & 3.3 & 1.0 & \\
\hline $12-27$ & 496 & 7.3 & 2.3 & $1.2-4.6$ \\
\hline $28-32$ & 313 & 4.8 & 1.5 & $0.6-3.4$ \\
\hline $33-37$ & 178 & 10.1 & 3.3 & $1.5-7.3$ \\
\hline$>37$ & 117 & 11.1 & 3.7 & $1.5-8.7$ \\
\hline \multicolumn{5}{|l|}{ Scholarship: } \\
\hline High school/college & 201 & 4.9 & 1.0 & \\
\hline Elementary/junior high school & 810 & 5.8 & 1.2 & $0.6-2.5$ \\
\hline Illiterate & 480 & 7.9 & 1.6 & $0.8-3.6$ \\
\hline \multicolumn{5}{|l|}{ Marital status: } \\
\hline Single & 719 & 7.6 & 1.0 & \\
\hline Widowed/divorced & 705 & 5.5 & 0.7 & $0.5-1.1$ \\
\hline Married & 61 & 1.6 & 0.2 & $0.01-1.4$ \\
\hline \multicolumn{5}{|l|}{ Number of children: } \\
\hline$>=1$ & 1175 & 5.7 & 1.0 & \\
\hline None & 308 & 9.1 & 1.7 & $1.0-2.7$ \\
\hline \multicolumn{5}{|l|}{ Working site: } \\
\hline Bar & 530 & 4.2 & 1.0 & \\
\hline Street & 816 & 7.6 & 1.9 & $1.1-3.2$ \\
\hline Other & 152 & 7.2 & 1.8 & $0.8-4.0$ \\
\hline \multicolumn{5}{|l|}{ Blood transfusion: } \\
\hline No & 1390 & 5.6 & 1.0 & \\
\hline Yes & 103 & 16.5 & 3.3 & $1.8-6.1$ \\
\hline \multicolumn{5}{|l|}{ Date of blood transfusion: } \\
\hline No BT & 1390 & 5.6 & 1.0 & \\
\hline After 1987 & 52 & 9.6 & 1.8 & $0.6-4.8$ \\
\hline Before 1987 & 41 & 24.4 & 5.4 & $2.4-12.1$ \\
\hline Unknown & 10 & 20.0 & 4.2 & $0.6-21.8$ \\
\hline \multicolumn{5}{|l|}{ Condom use: } \\
\hline No & 233 & 6.9 & 1.0 & \\
\hline Yes & 1265 & 6.2 & 0.9 & $0.5-1.6$ \\
\hline \multicolumn{5}{|l|}{ Time working in commercial sex: } \\
\hline$<1$ year & 271 & 4.4 & 1.0 & \\
\hline $1-5$ years & 804 & 6.1 & 1.4 & $0.7-2.8$ \\
\hline $6-10$ years & 252 & 7.5 & 1.8 & $0.8-3.9$ \\
\hline $11-15$ years & 85 & 7.1 & 1.6 & $0.5-4.9$ \\
\hline$>15$ years & 66 & 12.1 & 2.9 & $1.1-8.3$ \\
\hline \multicolumn{5}{|l|}{ Syphilis serology: } \\
\hline Negative & 1384 & 5.8 & 1.0 & \\
\hline Positive & 114 & 12.3 & 2.3 & $1.2-4.3$ \\
\hline
\end{tabular}

${ }^{\star}$ The number of observations vary because of missing values.

western blot at the National Institute for Epidemiological Reference, Mexico City.

All women having positive results were counselled and, when necessary, they received medical treatment.

ANALYSIS OF RESULTS

The mean difference in the number of FSW clients per week, categorised by workplace, was assessed by analysis of variance. Risk of HBV infection was estimated using odds ratio (OR) and the aetiological fraction among the exposed population (EFe) was calculated by dividing the absolute effect (due to blood transfusion (BT) precedent) by the $\mathrm{OR}$ of exposed individuals $(\mathrm{EFe}=\mathrm{OR}-1 / \mathrm{OR}) .^{5} \mathrm{Fi}-$ nally, mutivariate analysis was carried out by logistic regression to identify $\mathrm{HBV}$ infection predictors. The purpose of the multivariate analysis was to evaluate variables such as age, level of education, number of children, and frequency of sexual activity as potential confounders for the BT variable.

\section{Results}

On average the FSW population was 27.3 years old (range 17-57), and had given birth to 1.6 children, while $4.1 \%$ were married. From the population, $28.6 \%$ was born in Mexico City while the remainder originated from other states of the Mexican Republic. Street FSW were $54.5 \%$, while $35.4 \%$ worked in bars and
Table 2 Adjusted odds ratio of anti-HBc among Mexican female sex workers, by sociodemographic characteristics, sexual behaviour, history of blood transfusion, and syphilis serology in Mexico City during 1993

\begin{tabular}{|c|c|c|c|}
\hline Variable & $O R$ & $95 \% C I$ & p Value \\
\hline \multicolumn{4}{|l|}{ Age (years): } \\
\hline $16-22$ & 1.0 & & \\
\hline $12-27$ & 2.6 & $1.3-5.1$ & 0.007 \\
\hline $28-32$ & 2.2 & $0.9-5.1$ & 0.073 \\
\hline $33-37$ & 5.4 & $2.2-13.0$ & $<0.001$ \\
\hline$>37$ & 5.0 & $1.7-14.2$ & 0.003 \\
\hline \multicolumn{4}{|c|}{ Number of children: } \\
\hline$>=1$ & 1.0 & & \\
\hline None & 2.4 & $1.4-4.0$ & 0.001 \\
\hline \multicolumn{4}{|l|}{ Working site: } \\
\hline Bar & 1.0 & & \\
\hline Street & 2.4 & $1.4-4.3$ & 0.002 \\
\hline Other & 2.4 & $1.0-5.3$ & 0.039 \\
\hline \multicolumn{4}{|c|}{ Date of blood transfusion: } \\
\hline No BT & 1.0 & & \\
\hline After 1987 & 2.3 & $0.8-6.2$ & 0.095 \\
\hline Before 1987 & 4.8 & $2.1-11.3$ & $<0.001$ \\
\hline Unknown & 3.7 & $0.7-19.9$ & 0.126 \\
\hline \multicolumn{4}{|c|}{ Time working in commercial sex: } \\
\hline$<1$ year & 1.0 & & \\
\hline $1-5$ years & 1.2 & $0.6-2.3$ & 0.623 \\
\hline $6-10$ years & 1.1 & $0.5-2.4$ & 0.852 \\
\hline $11-15$ years & 0.8 & $0.3-2.4$ & 0.664 \\
\hline$>15$ years & 1.0 & $0.3-3.2$ & 0.973 \\
\hline \multicolumn{4}{|l|}{ Condom use: } \\
\hline No & 1.0 & & \\
\hline Yes & 0.8 & $0.4-1.6$ & 0.563 \\
\hline \multicolumn{4}{|c|}{ Syphilis serology: } \\
\hline Negative & 1.0 & & \\
\hline Positive & 1.9 & $0.9-3.5$ & 0.058 \\
\hline
\end{tabular}

$10.1 \%$ worked in hotels, massage parlours, or brothels. Only one respondent of the total FSW population acknowledged having occasional anal sex with a client and nine reported having occasional anal sex with their partner; none of these two groups tested positive for HBsAg, anti-HBc, or HIV. Moreover, no respondent reported injecting drug use.

The overall prevalence rate for $\mathrm{HBsAg}$ was $0.2 \%(3 / 1,498,95 \%$ CI $0.1-0.3), 6.3 \%$ for anti-HBc antibody $(95 / 1,498,95 \%$ CI $5.1-$ $7.5), 0.1 \%$ for anti-HIV antibody $(2 / 1,498$, $95 \%$ CI $0-0.3$ ), and $7.6 \%$ for $T$ pallidum antibodies $(114 / 1,498,95 \%$ CI $6.2-8.9)$.

There was no association between level of education and HBV infection (table 1). Not having children, however, was associated with a higher frequency of HBV infection.

The risk of HBV infection increases significantly with age, although there is no difference in risk of infection with client's condom use. The risk of HBV infection was significantly higher among street FSW compared with those who worked in bars. Women who received blood transfusion before 1987 had also a significant higher risk of $\mathrm{HBV}$ infection. The $\mathrm{EFe}$ calculation showed that from total cases of positive anti-HBc among 103 transfused women ( $\mathrm{n}=17), 73 \%(\mathrm{n}=12)$ were significantly associated with the antecedent of BT.

The risk of infection increased with the length of time prostitution had been practised, as well as with positive syphilis serology. The two females positive to HIV had no HBV markers.

Predictors of $\mathrm{HBV}$ infection were older age, street working, no parturition, and BT before 1987 (table 2). 


\section{Discussion}

The prevalence of $\mathrm{HBV}$ carriers (HBsAg positive) in this population of FSW from Mexico City was lower than that found in other countries- $0.2 \%$ v $1.7 \%, 4.6 \%$, or $6.1 \% .^{6-8}$ However, the prevalence was similar to that previously reported in the general population and in family blood donors in Mexico. ${ }^{12}$

Various authors have shown that certain population risk factors such as history of injecting drug use $\mathrm{e}^{9-11}$ and the practice of anal sex by FSW ${ }^{12}$ increase the probability of HBV infection in this segment of the population. Previous publications about Mexican FSWs have revealed a very low injecting drug use ranging from $0.6 \%$ to $1 \% .{ }^{413}{ }^{14}$ In the present study, the low prevalence of hepatitis B markers may be explained partly by the absence of injecting drug use and the infrequent practice of anal sex with clients or regular partners, and the low HBV endemicity in Mexico. However, we have to acknowledge that even though women from our sample denied injecting drug use, there might have been some underreporting of this risk.

Current results which support the hypothesis that HBV is sexually transmitted in FSW include the correlation of exposure periods and workplace with infection. Using the anti-HBc marker the risk of $\mathrm{HBV}$ infection increased with age and with the number of years that the subjects had worked as sex workers. In this latter case, the increased risk of infection was not significant following multivariate analysis.

Subjects who worked at street sites and those from "other" workplaces (hotels and brothels) were twice as likely to contract $\mathrm{HBV}$ infection than those who worked in bars. This result substantiates conclusions reached in another study which identified that subjects who worked at street sites had consistently higher risk of STD infection than subjects who worked in bars or massage parlours in Mexico City. ${ }^{13}$

The prevalence of anti-HBc in the FSW studied here can be partially explained by their history of BT. Controlled multivariate analysis has demonstrated that subjects with a BT history before the enforcement of HBV testing in Mexican blood banks ${ }^{15}$ had an infection risk
4.8 times higher than non-transfused subjects. Historical risk of $\mathrm{HBV}$ transmission is probably related to the lack of blood supply control in Mexico before 1987.

Additionally, women with no children had a higher $\mathrm{HBV}$ infection risk; however, there is currently insufficient information to substantiate this finding. This study is also a reminder that non-drug injecting sex workers' risk of HBV infection may depend on the community prevalence of the disease.

We thank Dr Janine Ramsey who revised the manuscript and Lab Tech Pilar Hernández-Nevárez who collaborated in sample processing.

1 Landa L. Seroepidemiología de la hepatitis B. Gac Med Mex 1976;111:108-11.

2 Herrera F. Seroprevalencia de la infección por el VHB (AgsHB) en donadores de sangre voluntarios familiares de la República Mexicana 1990-1992. II Congreso Iberoamericano de Bancos de Sangre y Medicina Transfusional, México 1993:84.

3 Juárez-Figueroa L, Uribe-Salas F, Conde-Glez CJ, et al. Hepatitis B markers in men seeking HIV antibody testing in Mexico City. Sex Transm Dis 1997;24:211-17.

4 Hyams KC, Escamilla J, Lozada R, et al. Hepatitis B infection in a non-drug abusing prostitute population in Mexico. Scand F Infec Dis 1990;22:527-31.

5 Kleinbaum DG, Kupper LL, Morgenstern H. Epidemiologic research: principles and quantitative methods. Belmont, CA: research: principles and quantitative methods. Bel

6 Hyams KC, Phillips IA, Tejeda A, et al. Hepatitis B in a highly active prostitute population: evidence for a low risk of chronic antigenemia. F Infect Dis 1990;162:295-8.

7 Bratos MA, Eiros JM, Orduña A, et al. Influence of syphilis in hepatitis B transmission in a cohort of female prostitutes. Sex Transm Dis 1993;20:257-61.

8 Orduña A, Bratos MA, Gutiérrez P, et al. Infection by hepatitis $\mathrm{B}$ and $\mathrm{C}$ virus in non-intravenous drug using female prostitutes in Spain. Eur f Epidemiol 1992;8:656-9.

9 Lange WR, Cone EJ, Snyder FR. The association of hepatitis delta virus and hepatitis $\mathrm{B}$ virus in parental drug abusers, 1971 to 1972 and 1986 to 1987. Arch Intern Med 1990;150:365-8.

10 Lettau LA, McCarthy JG, Smith MH, et al. Outbreak of severe hepatitis due to delta and hepatitis B viruses in severe hepatitis due to delta and hepatitis B viruses in
parental drug abusers and their contacts. $N$ Engl $\mathcal{F}$ Med

11 Blank RR, Ream N, Conrad M. Hepatitis B antigen and antibody in heroin users. Am $\mathcal{F}$ Gastroenterol 1979;71:164

12 Rosenblum L, Darrow W, Witte J, et al. Sexual practices in the transmission of hepatitis $\mathrm{B}$ virus and prevalence of hepatitis delta virus infection in female prostitutes in the United States. $\mathcal{F} A M A$ 1992;267:2477-81.

13 Uribe-Salas F, Hernández-Avila $\mathrm{M}$, Conde-Glez CJ, et al. Low prevalences of HIV infection and sexually tranmitted disease among female commercial sex workers in Mexico City. Am ₹ Public Health 1997;87:1012-15.

14 Güereña-Burgueño F, Benenson AS, Sepúlveda-Amor J. HIV-1 prevalence in selected Tijuana sub-populations. $A m$ HIV-1 prevalence in selected T

15 Norma técnica para la disposición de sangre humana y sus componentes con fines terapéuticos. Capítulo Sexto, Artículo 14, Fracción VII. Secretaría de Salud, México, 1986. 